\title{
Inspirations of ESP to English Teaching
}

\author{
CUI Jingjing \\ Jilin Business and Technology College \\ P.R.China, 130507 \\ 107851252@qq.com
}

\begin{abstract}
English for Specific Purposes (ESP), a widely applied advanced language teaching method abroad, hasn't gained sufficient attention in China. In recent years, however, more and more educators point out that ESP teaching should be the direction of English teaching reform in China. ESP English teaching plays an indispensable and decisive role in ESP development. This paper discusses difficulties in realization of ESP teaching and explores the approaches to Transformation of ESP teaching both theoretically and practically. Thus, we find out some inspirations of ESP in English teaching. It can make some contributions to promote college English reform.
\end{abstract}

Keywords-ESP; ESP teachers; ESP teaching; English teaching reform

\section{INTRODUCTION}

ESP, namely English for Specific Purposes, refers to English related to specific majors or disciplines, which serves as an English course developed and provided based on specific purposes and needs of learners. With diverse demands of the society on English proficiency and gradual increase in English proficiency of students not majoring in English, college English teaching is developing towards the exploration of reform in foreign language teaching and formation of ESP teaching method with Chinese characteristics. With frequent reference of ESP teaching in China's English teaching field in recent years, research on ESP teaching has been developing by leaps and bounds. However, realization and development of ESP teaching is far from being satisfactory and many problems exist. Firstly, positioning of ESP isn't very clear, for which even industry-based English, specialized English and bilingual teaching are included in scope of research on ESP. Secondly, specialized knowledge of ESP teachers becomes a challenging problem in realizing ESP teaching. Thirdly, under college English teaching model with Chinese characteristics, how to realize ESP teaching and define proportion of ESP courses in College English curriculum system become thought-provoking questions for foreign language researchers.

\section{ORIGIN \& THEORETICAL BASIS OF ESP}

With rapid scientific, technological, economic and cultural development around the world in the later period of the 1960s, EPS courses in college English teaching provided by colleges and universities in other countries emerged as the times required. With China's implementation of the opening up policy in the 1980s, international exchanges in various trades and professions became increasingly frequent, for which ESP course emerged gradually in colleges and universities in China. Although ESP teaching has a relatively late start in China, it has been getting increasingly important in colleges and universities and higher vocational schools with social and economic development and developing in a more rapid manner in recent years. As predicted by some foreign language specialists in China: Combination of English teaching with specialized knowledge in certain fields or disciplines will be more commonly seen in the future, and ESP teaching will be the mainstream of college English teaching in the 21st century. However, ESP teaching isn't equal to imparting of specialized knowledge, which emphasizes infusion of linguistic knowledge and training of the ability to use languages matching with specific specialties. As for definition of ESP, many researchers put forward their opinions. Hutchinson and Waters believe that: ESP shouldn't be deemed as a special language or a teaching method, which includes not only certain specialized teaching materials. In fact, it serves as a method for learning languages based on needs of learners.

Britain and the United States in the 1960s proposed ESP teaching theory in the field of applications linguists and its development has gone through five stages, namely language domain analysis or rhetorical discourse analysis, the target situation analysis, kills and strategies, and a learning-centered approach. The first three stages explore the characteristics of the surface structure of the language and the fourth stage explores the use of language in the thinking process and the fifth stage combines the study of language use and language application which not only concerned with social skills, talent and knowledge requirements, but also pay attention to students' learning needs.

\section{Difficulties IN REALIZATION OF ESP TEACHING}

ESP teaching students focus on pragmatic competence. Students don't aims at learning the language, but to learn the language through specific courses in order to apply English for certain work environment with working communicative competence. Under the present college English teaching models with Chinese characteristics, objects of teaching are college and university students not majoring in English. Because of size of the group and the large number of specialized disciplines, it is feasible to provide general English education to students, but it is impossible to realize uniform ESP teaching. Different teaching contents should be used by different classes and disciplines, and uniform teaching management and evaluation are also impossible. English teachers in colleges and universities don't have the ability to realize ESP teaching because they major in linguistic specialties generally and most of these teachers only have EGP teaching background but lack specialized knowledge in 
other specialties. Moreover, it is unrealistic to provide intensive trainings about other specialties to English teachers. If teachers majoring in other specialties are designated to conduct ESP teaching, their English proficiency isn't sufficient and satisfactory. Even students returning back to China after overseas study attach importance only to content and profoundness of specialized courses. In view of this situation, the abovementioned teachers aren't competent for ESP teaching. Furthermore, it is infeasible to organize and form a group of ESP teachers with the ability to complete language teaching and specialized knowledge in other specialties. Therefore, situation of teachers for ESP teaching becomes another difficulty in realization of ESP teaching. Lack of specialized knowledge in other specialties and the requirement of teaching by using a second language will result in lack of confidence among English teachers. In addition, students' understanding on learning of foreign languages only includes vocabulary learning, wording and phrasing, learning of answering questions for exercises and listening comprehension, which will lead to their reduced emphasis on ESP teaching. Lack of confidence among teachers and insufficient understanding among students will cause a poor ESP teaching atmosphere. Serving as a course based on a large platform, ESP course involves a relatively extensive range of specialties. There are various college English teaching materials, but they can't meet different requirements of various specialties in a uniform way. PB4 teaching for different purposes is based on extract and mixture of English teaching materials for certain specialties and thus lacks systematic features. The incomplete system of teaching materials also becomes a difficulty faced by ESP teaching.

\section{ApPROACHES to TRANSFORMATION OF ESP TEACHING}

\section{A. Transformation of Concepts \& Reasonable Positioning}

Although some achievements in ESP teaching in colleges and universities have been made, teaching effect isn't optimistic. Unclear positioning, single teaching method, low quality of teaching materials and lack of standardization of teaching test, based on which some measures were put forward, including specifying positioning of ESP course, speeding up development and preparation of ESP teaching materials, intensifying training for ESP teachers, establishing online ESP resource library, etc. In order to improve social adaptation of English teaching provided in higher vocational schools, we have to transform concepts and specify positioning of ESP course provided in English teaching by higher vocational schools. Based on ESP courses provided at present, ESP courses are provided as optional courses in most of higher vocational schools. In this way, English teaching can be liberated from discipline-based or knowledge-based courses and get close to a specialty-based course, which emphasizes training of students' vocational English proficiency and improves their professional competitiveness and social adaptation and thus realizes real unification between teaching objectives and learning needs.

\section{B. Handling of Relationship between Basic English \& English for Specific Purposes in an Appropriate Manner}

Generally, practical English courses provided in colleges and universities, namely EGP course, have the purposes of imparting linguistic skills and cultivating five basic skills of students, including listening, speaking, reading, writing and translating skills, for which teaching contents involve general linguistic knowledge and skills and students aim to pass examinations through learning. Therefore, such courses aren't occupation-targeted and thus can't meet demands of specific industries in the society. According to survey result, $67.5 \%$ of teachers and students don't feel satisfied with practical English courses now provided by colleges and universities. They believe that those teaching methods used in middle schools are still being used in English teaching and learning based on such courses provided in colleges and universities, which emphasize vocabulary and grammar teaching and are divorced from requirements of practical work in the future. Obviously, traditional practical English teaching isn't consistent with needs of students and vocational needs. However, ESP courses emphasize imparting of linguistic knowledge and cultivation of corresponding ability to use a language, which are clearly purpose-based and have objectives of consolidating students' EGP knowledge and improving their ability to use English language in real works and thus meeting needs of specific industries in the society. It is evident that as for ESP courses; the relationship between basic English and English for Specific Purposes should be handled in a proper way. EGP courses shouldn't be ignored or even cancelled because of ESP courses because EGP serves as the basis while ESP enables combination of training of linguistic skill and learning of specialized knowledge and serves as the extension of EGP teaching. In other words, students are able to learn ESP courses based on a certain degree of EGP basis. As for arrangement of English courses, EGP and ESP should be combined and natural connection between teaching contents of these two courses should be implemented for the purpose of making ESP teaching permeate the whole process of English teaching and reflecting vocation-based and application-based features of English courses. Meanwhile, based on requirements of industries and enterprises on English proficiency of highly skilled talents, career-oriented feature should be emphasized and English teaching should be geared to serve professional education and occupational application.

Therefore, we have to insist on the relationship between teaching basic English and ESP. For the students with bad foundation are mainly learned basic English, meanwhile, for the students with a good foundation should not be heard and other basic capabilities. Teachers should let them into English for ESP courses as soon as possible. For colleges, especially for the general colleges and universities, basic English teaching can be more, ESP as an elective; and "national key universities should shift the public English to bilingual teaching mode, that is to say, ESP teaching should gradually become the mainstream of college English teaching in these universities. This kind of approach will not only affect students' promotion of English, but also to promote language learning efficiency. This acquisition by foreign language learning expertise approach can be an ideal model of language learning 


\section{Intensifying Training of ESP Teachers}

The interdisciplinary nature of ESP course has double requirements on language proficiency and specialized knowledge of teachers. Hutchinson \&Waters believe: It isn't necessary for ESP teachers to learn in-depth specialized knowledge; however, they should grasp some basic knowledge in certain specialties and basic linguistic features in those specialties. Dudley-Evans and St John (1998) [1] also have special expositions about ESP teachers: Firstly, a qualified ESP teacher should be a qualified English teacher. Therefore, an outstanding ESP teacher should have not only great basic English skill but also English teaching methods and relevant specialized knowledge. At present, teachers can be categorized into two types: Teachers of the first type include those trained English teachers, and teachers of the other type include those specialized teachers with relatively higher English proficiency. However, a certain degree of disadvantage still exists when ESP courses are taught by either English teachers or specialized teachers: Affected by traditional concepts about foreign language education and teaching models used in China, most of English teachers grasp a foreign language but have no specialized knowledge and usually use the teaching model applied in EGP teaching, so they can't be competent at teaching of ESP courses. However, specialized teachers have a relatively poor language communication skill and barely understand advanced language teaching theories, so they can't cultivate students' language learning skill and strategy in an effective way. For the purpose of learning about the current situation of ESP teaching, the author attended some classes in English for Tourism and English for Conference \& Exhibition provided by Tourism Department. Result indicates that: Due to lack of specialized knowledge, English teachers usually conduct ESP teaching by using those methods applied in teaching basic English. However, due to lack of language teaching experience, specialized teachers tend to teach ESP course in a way that is used in teaching specialized courses. It seems that these two teaching models only combine English and other specialties but involve no linguistic features and communication skills in ESP, for which it is very difficult to improve students' ability in using English language in a comprehensive way.

\section{Effective Platform Realizing ESP Teaching}

Firstly, developing optional English course is one of those effective approaches to realization of PB4 teaching. ESP teaching can be realized through optional course of college English based on different specialties and different needs of students in various colleges and universities, such as providing some optional courses with a relatively high degree of applicability including Business English, Journalistic English, Medical English, English for Chemical Industry, English for Computer Science, English for Tourism, English for Finance \& Economics, Engineering English, Legal English for the purpose of meeting special requirements of students majoring in different specialties. Classes for such courses may be big or small in size. English teachers may develop personalized optional courses based on their interests and knowledge in some fields and prepare different syllabuses for different optional courses. Meanwhile, they may also design different teaching objectives, teaching requirements, evaluation systems, etc. Importance should be attached to linguistic knowledge in English language as for teachers of optional courses for ESP, and it isn't necessary to have high demand on specialized knowledge involved in teaching of such courses and general understanding of such knowledge is acceptable, which can absolutely be realized through learning effort of ESP teachers or appropriate communications with specialized teachers. Although it is impossible to develop ESP courses for all specialties, developing optional courses of college English is a feasible approach to realization of ESP teaching.

\section{E. Improve Teaching Methods, Student-centered}

Traditional ESP teaching is teacher-centered which is in the core of explaining the jargons and translating articles. There is little interaction between teachers and students. Students only can be a loyal audience and often feel boring. At the same time, there is an ineffective teaching. Modern ESP teaching should be student-centered, based on student and external demand, which uses the communicative approaches to arrange lectures with financial, authentic and professional knowledge and combines with modern and functional language laboratories and network resources interestedly. Teachers can integrate cultural factors to account for the textual knowledge with professional exchange of information involved rhetorical skills. Such as in business English teaching, teachers can show a variety of commercial bills and model contracts and other inkind to the students and arrange students to have group discussions, dialogue, RPG, debate pros and cons, case study to live simulation teaching activities. Teachers can change a single and inflexible classroom teaching method in order to realize efficient atmosphere in language learning and language use integration.

\section{CONCLUSION}

In a word, ESP courses serve as skill-based and application-based English courses with industrial characteristics and should be closely connected with requirements of professional, social and economic development, which are also combined with future careers of students and can meet demand of market on talent training and cultivation. As a matter of fact, as for English teaching in higher vocational schools, students will definitely be well trained and become interdisciplinary and practical talents meeting demands of social and economic development only through extension of EGP teaching to ESP teaching, reasonable positioning of ESP courses, proper handling of relationship between EGP teaching and ESP teaching and intensifying training and cultivation of teachers for ESP courses. Here should be a striking contrast between ESP and EGP.

\section{REFERENCES}

[1] Dudley Evans, St John. Development in English for Specific Purposes [M]. Cambridge: Cambridge University Press, 1998.

[2] Hutchinson T, W aters A. English for Specific Purposes: A Learnercentered Approach [M]. Cambridge: Cambridge University Press, 1987.

[3] Richards J C. The Language Teaching M atrix[M]. Cam-bridge: Cambridge University Press, 1990. 
[4] Robinson P. ESP Today: A Practitioner's Guide[M ]. U.K.:PrenticeHall International Group, 1991.

[5] Strevens P. ESP after Twenty Years: A Re- appraisal[C] Chamberlain D, R J Baumgardner. ESP in the Classroom: Practice and Evaluation. U. K.: Modern English Publications, 1988.

[6] Caijigang. ESP and the development direction of college English teaching [J]. Foreign Language,.2004( 2).
[7] Wang Shou ren. Development of Chinese Teaching English for Specific Purposes, Promoting Chinese study English forSpecific Purposes [J].Chinese study English for Specific Purposes.2010(1):5-6.

[8] Zhangraoxue, Intensify Applicable English Teaching and Promote College Student Comprehensive Ability, [J]. Chinses Educatio, 2002,(8). 